\title{
Melville J. Herskovits (1895-1963) e a antropologia do Caribe - entrevista com Kevin A. Yelvington
}

\author{
— entreVistador e tRAdUTOR: RodRIGO RAMASSOTE \\ Universidade de São Paulo, São Paulo, São Paulo, Brasil
}

DOI 10.11606/issn.2316-9133.v25i25p343-364

Esta entrevista foi realizada com Kevin A. Yelvington, professor do Departamento de Antropologia da Universidade do Sul da Florida (USF), Tampa (EUA). Especialista na região etnográfica do Caribe, autor de livros e artigos sobre etnicidade, relações de gênero e condição de classe em Trinidad, Yelvington tem se debruçado, entre outros projetos de pesquisa, sobre a trajetória intelectual e a produção intelectual de Melville J. Herskovits, o principal estudioso da África e da Afro-América na antropologia norte-americana na primeira metade do século XX. ${ }^{1}$ A partir do levantamento de informações em arquivos norte-americanos e no exterior (incluindo o Brasil) e entrevistas com ex-alunos e pessoas próximas a Herskovits, Yelvington vem reconstruindo os fundamentos teórico-conceituais, as influências e débitos intelectuais, a rede de contatos e interlocutores, a inserção institucional e as atividades formativas, as críticas sofridas e o legado deixado por Herskovits.

A entrevista se divide em três partes. Na primeira, a conversa gira em torno da biografia, da formação acadêmica e do projeto intelectual de Herskovits, com especial ênfase nas pesquisas de campo realizadas por ele. Em seguida, na segunda, sobressai a contribuição e o legado de Herskovits para a constituição de uma agenda de estudos antropológicos no Caribe, seja por meio de sua própria produção, seja por meio da obra de seus alunos e discípulos. Por fim, na terceira se avança para os principais temas antropológicos de pesquisa que marcaram os estudos dedicados ao Caribe, dos anos 1980 ao momento atual.

Sugiro começarmos por uma pergunta de ordem pessoal: em que circunstâncias e por quais razões você se interessou pelo trabalho do antropólogo Melville J. Herskovits?

KAY: Ao realizar minha dissertação de mestrado (YELVINGTON, 1985), utilizei de modo crítico o conceito de aculturação, que se tornou, durante um

${ }^{1}$ Dessa empreitada alguns resultados parciais já foram publicados: Magloire e Yelvington (2005); Yelvington (2000; 2001; 2006; 2007; 2008). 
longo período, predominante nas ciências sociais norte-americana. Melville J. Herskovits foi um dos seus principais proponentes e há toda uma dimensão política por trás, sobre a qual podemos discorrer mais tarde. De qualquer maneira, ele elaborou o conceito de aculturação a partir de formulações legadas por Franz Boas, transformando-as em um objeto de estudo antropológico. Eu já estava, portanto, familiarizado com o trabalho de Herskovits quando fui cursar meu doutorado na Universidade de Sussex, na Inglaterra. Meu orientador, David Harrison, foi aluno do antropólogo jamaicano M.G. Smith na University College London. Smith, por sua vez, estudou com Darryl Ford e foi à Nigéria fazer pesquisa de campo, seguindo depois para o Caribe. Ele discordava de Herskovits a respeito de uma série de questões teóricas, da importância das sobrevivências africanas no Novo Mundo e da melhor maneira de caracterizar a sociedade caribenha. Harrison, ao tornar-se aluno de Smith, iria inicialmente reestudar Toco, em Trinidad, onde o casal Melville J. e Frances Herskovits fez pesquisa de campo, em 1939 (HERSKOVITS, 1946). Ao final, por várias razões, ele pesquisou em uma vila próxima a Toco, mas não propriamente em Toco. Em nossas conversas, ele me aconselhava: "Se você for fazer antropologia do Caribe, deve aprofundar suas leituras de Herskovits". A fim de me preparar para a pesquisa de campo em Trinidad, na qual se baseou minha tese de doutorado (YELVINGTON, 1995), eu reli os principais trabalhos de Herskovits. Ele não era pertinente para as preocupações centrais de meu estudo, que versou sobre gênero, classe e etnicidade, com base em pesquisa etnográfica com mulheres operárias de uma fábrica de eletrodomésticos no contexto de um país subdesenvolvido. Mas o interesse por sua obra permaneceu.

Além disso, eu estava interessado - e continuo - nas condições sociais e políticas de produção, difusão e recepção de formulações teóricas. E o caso de Herskovits, nos Estados Unidos, me fascinava: suas teorias sobre as sobrevivências culturais africanas, que ele chamava de "Africanismos", foram retomadas nos anos de 1960 e 1970 na esteira da luta pela ampliação dos direitos civis e afirmação e valorização da identidade afro-americana, após um período de relativo esquecimento, por força da preocupação, por parte de estudiosos e ativistas, com a integração racial nos Estados Unidos, sobretudo nos anos de 1940 e 1950.

Outro ponto que me levou a Herskovits foi o interesse pela história da antropologia - estou me referindo ao final dos anos 1980 e começo dos 1990. Nessa altura, a história da antropologia estava se tornando uma subárea de investigação e pesquisa relevante, especialmente com os trabalhos de George W. Stocking Jr. (1968) e Regna Darnell (1998), nos Estados Unidos e no Canadá; os trabalhos de Mariza Corrêa (1987) e Sergio Miceli (1991), no Brasil. Na Inglaterra, o livro de Adam Kuper, Anthropology and Anthropologists, publicado em 1973, ainda era bastante lido e comentado.

Do ponto de vista pessoal, eu já era pai - tenho duas filhas, Cristina e Amanda - e não parecia viável fazer pesquisa de campo em algum lugar distante por 
um ou dois anos, enquanto elas fossem pequenas. Assim, comecei a devotar meu tempo a ser um historiador da antropologia, fazendo pesquisa em arquivos por alguns dias e voltando para casa rapidamente. No início, eu acabei pagando do meu próprio bolso a alguns estudantes da Northwestern University, onde a maior parte do acervo documental de Herskovits está arquivado, para fazer fotocópias dos documentos e enviá-los para mim. E isso só foi possível graças à ajuda dos incríveis arquivistas da Northwestern. Com esse arranjo, eu poderia fazer pesquisa "em casa" e assim acompanhar de perto o crescimento de minhas filhas, o que me deixou muito, muito feliz. Acrescente ainda minha relação com a América Latina e o Caribe, que sem dúvida foi estimulada pelo fato de eu ter nascido e crescido em Miami, cidade que de algum modo é uma das “capitais" da América Latina e do Caribe.

Por fim, fui formado na Escola Britânica de Antropologia e, ao voltar para os Estados Unidos, precisava entender melhor a tradição norte-americana - a antropologia cultural de Franz Boas e seus discípulos -, a qual, ironicamente, conhecia menos do que a inglesa, da qual eu havia aprendido tanto com o livro de Kuper quanto com os trabalhos de Henrika Kuklick (1991), Ian Langham (1981), Michael W. Young (1979) e outros. Assim, uma combinação de interesses intelectuais, de um contexto acadêmico específico e de minha história pessoal explica o fato de eu querer aprofundar meu conhecimento sobre Herskovits.

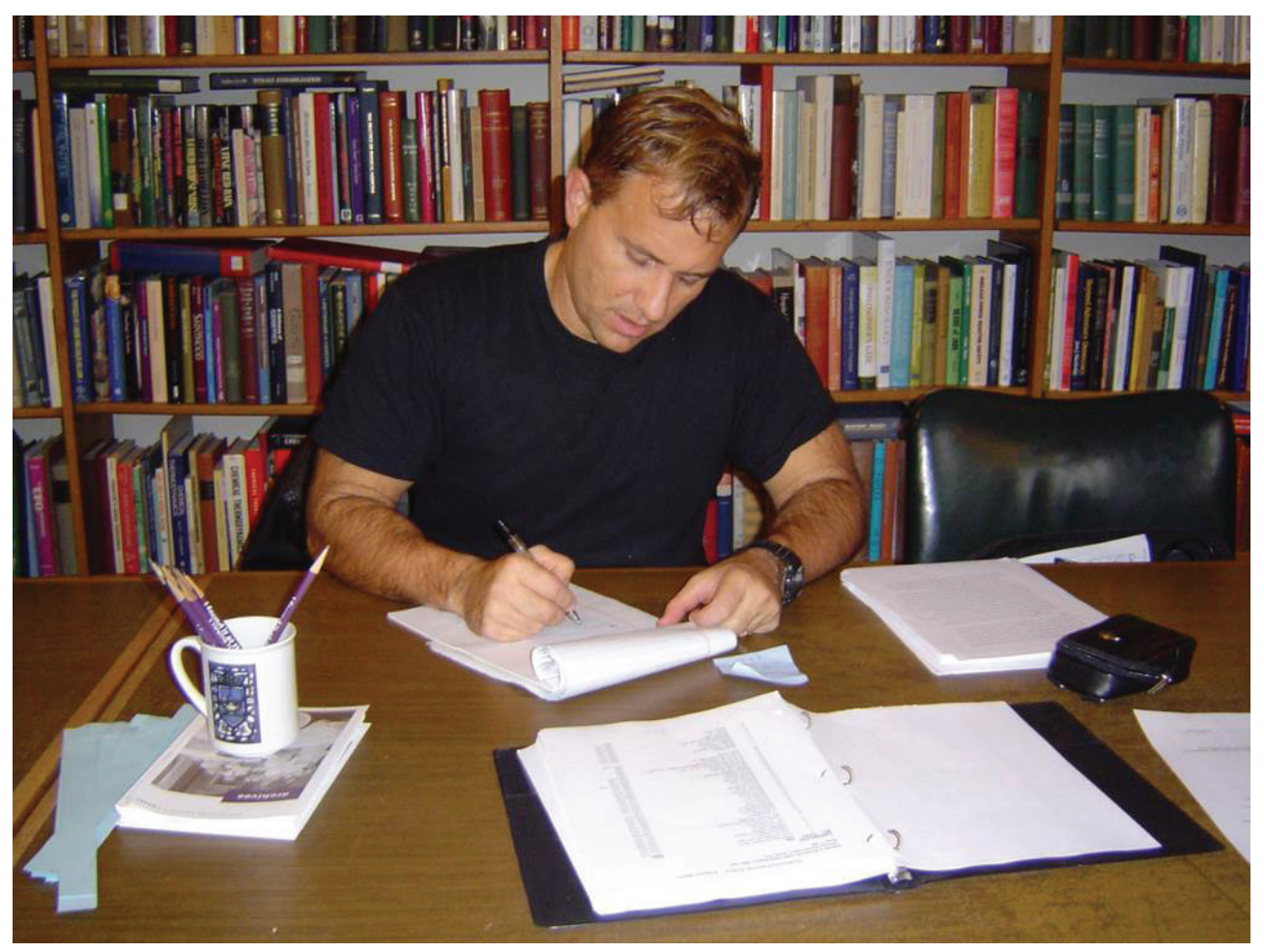

Foto Kevin A. Yelvington pesquisando nos arquivos da Northwestern University. Acervo pessoal do autor. 
Em um artigo publicado na revista Survey Graphic, em 1925, Herskovits constatou que não havia "nenhum traço" da cultura africana no Harlem (NY) e que o bairro era essencialmente uma comunidade norte-americana. Poucos anos depois, ele rapidamente estabeleceu sua reputação como o maior pesquisador das populações afro-americanas e africanas nos Estados Unidos, dedicando seu projeto intelectual ao rastreamento da distribuição e intensidade das sobrevivências culturais africanas no Novo Mundo. Como você explica essa drástica guinada?

KAY: Herskovits defendeu sua tese de doutorado na Universidade de Columbia, em 1923, sob a orientação de Franz Boas. The Cattle Complex in East Africa (1926), publicada em quatro números sucessivos da American Anthropologist, resultou em um estudo bibliográfico sobre áreas culturais e a importância do gado na região Leste da África. Entre outras fontes de informação, ele utilizou a biblioteca pessoal do intelectual afro-americano W. E. B. Du Bois. Em seguida, Boas obteve para Herskovits uma bolsa do National Research Council para fazer pesquisas em antropologia física, sobre raça e a formação da "raça negra", entre os anos de 1923 e 1926. Parte dessa investigação foi feita na Howard University, em Washington, D.C, historicamente uma universidade de estudantes e professores afro-americanos. Lá ele conviveu com Alain Locke, filósofo pragmático, ativista social e fundador do movimento "Harlem Renaissance". Pelo fato de Herskovits estar também pesquisando no Harlem - com a colaboração de Zora Nearle Hurston, antropóloga e escritora afro-americana, aluna de Franz Boas, que fez trabalho etnográfico na região Sul dos Estados Unidos, na Jamaica e no Haiti -, Locke convidou-o para escrever um artigo em um número especial de Survey Graphic sobre o Harlem, por ele editado em março de 1925.

Herskovits, um dos poucos autores brancos daquele número, foi o único a assumir uma postura assimilacionista, ao afirmar que o Harlem era como qualquer outra comunidade negra nos Estados Unidos, com as mesmas características, por exemplo, do Rotary Club de sua cidade natal, em Ohio. Ele concluía o artigo declarando: “O mesmo padrão, apenas uma tonalidade diferente!”. Isto é, o mesmo padrão cultural, apenas uma coloração mais escura da pele. No meio das páginas do artigo de Herskovits, Locke inseriu um comentário numa caixa de texto - o que é algo extraordinário: um editor inserir um comentário dentro texto de outro autor! -, no qual ele sugeria que talvez Herskovits quisesse reavaliar sua opinião e aprofundar o assunto.

Não esqueça que tudo isso ocorreu em meio à agitação provocada pelo Harlem Renaissance, quando o bairro era o centro de uma intensa produção literária e artística de afro-americanos. Era o período da chamada Grande Migração [Great Migration], no qual levas de afro-americanos deixaram o Sul segregacionista e se deslocaram para o Norte. No caso do Harlem, muitos migrantes vieram dos estados da Georgia, das Carolinas do Sul e do Norte e da Virginia. O 
número especial de Survey Graphic transformou-se, pouco depois, no livro The New Negro: an Interpretation (1925), um documento clássico do Harlem Renaissance. Ao se transformar num capítulo, o artigo de Herskovits permaneceu o mesmo, mas o comentário de Locke foi retirado. Um pouco depois, Herskovits elaborou um plano de estudos e submeteu um pedido de financiamento tanto ao National Research Council quanto à Universidade de Columbia, que também disponibilizava recursos para projetos de seus alunos e ex-alunos, no qual ele delineou um programa de pesquisa sobre a diáspora africana para o Novo Mundo, numa perspectiva bastante diferente do artigo e do capítulo sobre o Harlem.

Então, como considerar essa mudança de orientação? Em primeiro lugar, não podemos minimizar o comentário de Locke, que certamente mexeu com Herskovits. Eu acho que ele leu os demais artigos daquele número da Survey Graphic, incluindo o trabalho de Arthur Schomburg, o bibliófilo e bibliotecário afro-porto-riquenho, e outros que se tornariam, nos anos seguintes, escritores, cientistas sociais e historiadores de renome, todos assumindo uma posição oposta.

Outra razão é que Herskovits começou a ler outras fontes bibliográficas, incluindo escritos de viagem e de cientistas sociais. Ele foi bastante influenciado pela grande folclorista norte-americana Elsie Clews Parsons, que fez pesquisa no Caribe e sugeriu que ele estudasse os Marrons do Suriname - os Marrons são comunidades de negros que escaparam da escravidão e se refugiaram no interior da Guiana Holandesa, onde se dividiram em quatro tribos. Segundo Parsons, Herskovits poderia encontrar entre eles a África na América. De fato, ela financiou seu trabalho de campo, em 1928 e 1929, no Suriname, onde ele fez pesquisas com os Saramakas, juntamente com sua esposa, Frances S. Herskovits. Ao mesmo tempo, ele entrou em contato com o livro de viagens Tom-Tom (1926), escrito pelo norte-americano John W. Vandercook, sobre os "Bush Negroes" do Suriname, no qual o autor defendia a tese das sobrevivências culturais africanas.

Em terceiro lugar, creio que também contribuiu para a mudança o fato de ele ter articulado uma rede transatlântica de correspondentes da América Latina e do Caribe, em sua grande maioria etnólogos amadores, mas de grande valor. Por meio de cartas e remessas de livros e separatas, ele comunicou-se como Jean Price-Mars, médico, político e também etnólogo no Haiti; Fernando Ortiz, advogado e etnólogo amador em Cuba, e outros tantos. Um pouco depois, no Brasil, com o médico e antropólogo Arthur Ramos. Herskovits começou a ler as obras de Raimundo Nina Rodrigues e um grande número de outros pioneiros no estudo da diáspora africana.

Acho também importante mencionar que Herskovits foi um boasiano estrito. O que ele fez estava prefigurado na agenda temática de Franz Boas. No esquema de Boas, havia espaço tanto para a perspectiva assimilacionista, como a que Herkovits defendeu no Harlem, como também havia espaço para as sobrevivências culturais, uma vez que pois Boas não era exatamente categórico em suas 
proclamações teóricas. Há passagens em escritos de Boas em que ele afirma que "fragmentos de estágios históricos anteriores devem existir e são encontrados no presente".

Herskovits, de várias maneiras, encaixa-se no perfil dos estudantes de Boas. Ele era filho de imigrantes judeus europeus. Seu pai era originário do Império Húngaro e sua mãe da Alemanha. Eles se encontraram nos Estados Unidos e o pai virou comerciante. Melville nasceu em Bellefontaine, Ohio, em 1895. Em sua casa, a mãe insistia que os filhos tivessem lições de música - ele tinha uma irmã mais velha, Charlotte. De fato, Charlotte tornou-se uma exímia musicista, trabalhando o resto da vida como professora de música. Melville era uma espécie de prodígio com o violino quando muito jovem. Como sua mãe, Henrietta, contraiu tuberculose e ficou muito doente, a família mudou-se para El Paso, Texas, por conta do clima seco e quente. Lá, eles se envolveram com a comunidade judaica local e Melville foi muito atuante em seu templo. Ele foi um judeu reformado, que não teve um bar mitzvah, mas apenas uma cerimônia de confirmação. Nessa época, trabalhou como entregador de jornais, arremessando-os de um carrinho ao longo do trajeto que ligava, por uma ponte, El Paso a Juárez, no México, onde se concentravam comerciantes americanos que haviam aberto lojas, muitos dos quais ligados à comunidade judaica em El Paso. Era o tempo da Revolução Mexicana, em 1910. Melville, ainda adolescente, trouxe sua câmera fotográfica e registrou os incidentes na área de fronteira de El Paso.

Infelizmente sua mãe não resistiu à doença. Com a morte dela, seu pai mudou-se para Erie, Pennsylvania, onde abriu uma nova loja e onde Melville concluiu o ensino secundário. Nessa altura, ele ainda acalentava se tornar um rabino, tanto que em seus diários ele registra que um rabino poderia ter uma vida incrível, aprendendo o tempo todo. É interessante notar que ele não manifestava muito fervor religioso, enfatizando a dimensão intelectual, o lado erudito exigido pela profissão. Isso é importante, pois ele vai para o Hebrew Union College, em Cincinnati, ao mesmo tempo que ingressa na Universidade de Cincinnati. Em pouco tempo, ele tem uma espécie de crise de fé e pergunta a um de seus colegas de turma o que deveria fazer sobre questionar seriamente certos conceitos teológicos. Um colega lhe perguntou: "Você é capaz de rezar pelas forças sociais e chamá-las de Deus em sua cabeça?”. Herskovits não se satisfez com a resposta, abandonando a ideia de tornar-se um rabino para ingressar no exército norte-americano e servir na Primeira Guerra Mundial. Em 1917, ele se alista e torna-se parte do Corpo Médico, sendo lotado na França.

Acredito que a experiência da guerra o marcou profundamente, como tantos outros americanos. Em 1919, após o armistício, ele retornou aos EUA e assistiu ao chamado "Verão Vermelho" [Red Summer], um período marcado por revoltas raciais e linchamentos de afro-americanos, incluindo afro-americanos ainda com o uniforme de guerra. E tais fatos não se restringiram à região Sul dos EUA, onde infelizmente eles ocorriam com certa frequência: eles ocorreram também 
no Norte. Herskovits estava em Chicago quando o "Verão Vermelho" irrompeu. Ele nunca falou sobre isso em seus diários. Eu sei disso porque entrevistei, por cinco vezes, sua filha, Jean Herskovits, historiadora de África. Creio que tais fatos o marcaram. Como não poderiam?

Herskovits transferiu-se para a Universidade de Chicago e concluiu um bacharelado em História. Em seguida, foi para Nova York, onde iniciou um mestrado em Ciências Políticas na Universidade Columbia, entrando em contato com um grupo de intelectuais que iria moldar o seu futuro, especialmente Franz Boas. Entre seus colegas de turma estavam, entre outros, Margaret Mead, Rüdiger Bilden (o grande amigo de Gilberto Freyre) e Ruth Benedict. Em Columbia, conheceu sua futura esposa, Frances Shapiro, filha de migrantes judeus da Rússia. Sua dissertação de mestrado tinha como tema as greves trabalhistas no estado de Washington - ele usava um broche da IWW (Industrial Workers of the World, os chamados "Wobblies") -, apoiava o movimento feminista e considerava-se como parte da avant-garde. Herskovits estudou na New School for Social Research com Elsie Clews Parsons e Thorstein Veblen, cujas ideias the foram muito importantes. Como mencionei, após defender o doutorado, ele foi beneficiado com uma verba do National Research Council para uma pesquisa em antropologia física, na qual ele defendia que o negro norte-americano era uma nova raça, um amálgama de raças.

Em 1927, ele ingressa, como professor-auxiliar, no Departamento de Sociologia da Northwestern University, sendo o seu único antropólogo. Poucos anos depois, em 1938, o Departamento de Antropologia é criado e ele se torna seu chefe até 1956. Herskovits fez toda a carreira na Northwestern, até sua morte, em 1963. Pesquisou, como mencionei, com sua mulher Frances, no Suriname, em 1928 e 1929; na África Ocidental, no Daomé, hoje Benin; na Nigéria; e na Costa do Ouro, hoje Gana, em 1931; em 1934, no Haiti; em 1939, ele e Frances foram a Trinidad; e em 1941 e 42, em vários lugares do Brasil, especialmente Salvador.

Você acredita, como Walter Jackson sustenta em Melville Herskovits and the Search for Afro-American Culture (1986), que o contato de Herskovits com o Harlem Renaissance e sua passagem pelos quadros da Universidade Howard tiveram um profundo impacto em sua carreira? Eu continuo pensando nos fatores que levaram à radical guinada que discutimos. Como você vê a relação de Herskovits com os intelectuais negros nos Estados Unidos?

KAY: Eu creio que os anos passados por Herskovits na Universidade Howard foram muito importantes. Além de ensinar antropologia física e fazer pesquisas genealógicas com os estudantes, ele também se aproximou de intelectuais afro-americanos, como Abram L. Harris, economista que o ajudou com a pesquisa; o sociólogo E. Franklin Frazier, com quem teve uma "disputa" em termos teóricos e políticos que se estendeu no tempo; Alain Locke, entre outros. Esse período 
foi importante para Herskovits no que se refere a seu desenvolvimento intelectual. Por outro lado, ele nem sempre teve um bom relacionamento com parte da intelectualidade afro-americana. É o caso, por exemplo, do historiador Carter G. Woodson, que sustentava quase os mesmos argumentos que Herskovits em suas publicações. Havia hostilidade mútua entre eles.

Eu mencionei acima W. E. B. Du Bois, um grande amigo de Franz Boas. Em companhia de Du Bois, Boas foi um dos fundadores do NAACP (National Association for the Advancement of Colored People). Ele proferiu um famoso discurso em 1906 para os estudantes de pós-graduação da Atlanta University, onde Du Bois era professor e declarava a seus alunos que eles tinham um passado cultural de origem africana do qual deveriam se orgulhar. Herskovits de certo modo herdou e manteve esta relação amistosa com Du Bois. Quando este foi para Chicago, Herskovits o convidou para ingressar no Clube dos Professores da Northwestern. Um ato de muita coragem, pois convidar um negro para o clube de uma universidade não era comum naquela época - e mais corajoso ainda se lembramos que o próprio Herskovits era apenas o segundo judeu do corpo docente da Northwestern e também sofria discriminação. Por outro lado, quando Du Bois, pouco depois, tentou levantar recursos para a realização de sua Encyclopedia of the Negro junto às maiores fundações norte-americanas e estas solicitaram a opinião de Herskovits sobre o assunto, ele não recomendava o financiamento porque, ainda que $\mathrm{Du}$ Bois fosse um grande pesquisador, receava que o projeto se tornasse obra de propaganda - ele tinha receio dos colaboradores de Du Bois, em sua opinião mais propagandistas do que cientistas sociais. Isso ocorria, claro, nos bastidores. Du Bois não tinha consciência. Por outro lado, quando Du Bois estava na Universidade Atlanta e houve uma questão a respeito do cancelamento de sua aposentaria, Herskovits escreveu uma carta cheia de fervor ao reitor da universidade, dizendo que Du Bois era um grande pesquisador e que não deveriam tratá-lo de maneira desrespeitosa.

Quando Herskovits iniciou o Committee on the Negro, em 1940, para o American Council of Learned Societies, ele não incluiu muitos dos intelectuais afro-americanos no comitê. Convocou, por exemplo, Lorenzo Dow Turner, que fez pesquisa de campo na Bahia junto com Frazier e cuja perspectiva coincidia com a de Herskovits. Ele tendia a criar fronteiras ao redor de si mesmo e de pesquisadores que concordavam com suas posições teóricas e excluir aqueles que discordavam. Eu creio que há uma série de questões que ainda estão em debate sobre Herskovits acreditar ou não que os antropólogos afro-americanos seriam capazes de estudar com objetividade a África e a Afro-América.

Você poderia caracterizar o programa de pesquisas de Herskovits sobre as sobrevivências culturais africanas no Novo Mundo de um ponto de vista teórico, metodológico e conceitual? 
KAY: Como eu disse, Herskovits era um boasiano estrito e seus temas de pesquisa são basicamente reelaborações de questões formuladas por Boas. É o caso, por exemplo, de um de seus conceitos-chaves: aculturação. Aculturação é um termo que descreve o contato de culturas, quando uma cultura influencia a outra. Para Boas, esse processo era guiado pelo "Geist" de uma cultura particular, isto é, o "gênio de um povo". Assim, uma determinada cultura absorve e molda os elementos externos para encaixá-los em seus próprios padrões. Para Herskovits, no processo aculturativo da diáspora africana para o Novo Mundo, os elementos culturais de origem europeia se sobrepõem a padrões culturais africanos pré-existentes. Estes sobreviveriam num nível mais profundo.

Outro conceito-chave, "foco cultural", que já aparecia em Boas, talvez não com essa designação, é retomado e reintroduzido no debate por Herskovits. Boas já havia dito que a imaginação humana era limitada e tendia a focalizar em um ou outro elemento-chave. Herskovits acreditava que a cultura dos povos afro-americanos enfocava questões religiosas e questões performáticas, como a música e a dança. Tratava-se, segundo ele, da área em que eles depositam suas energias, em razão, como ele talvez apontasse, do contexto da escravidão e da discriminação. Ele tentava dar conta do processo de mudança, mas de fato as coisas permanecem as mesmas ao serem "reinterpretadas" através de esquemas culturais previamente estabelecidos. Pode-se acompanhar o uso desses conceitos ao longo de sua carreira, a partir dos quais ele confere mais ou menos ênfase a alguns aspectos.

Herskovits reivindicava uma perspectiva histórica, novamente na esteira de Boas, ainda que nunca tenha feito pesquisas em arquivos. Ele se valia de fontes secundárias disponíveis e julgava que estava adotando uma abordagem histórica para apreender a questão da mudança cultural. Porém, na realidade, era uma mudança que não ocorria. Ele, sem dúvida, acreditava nos princípios metodológicos boasianos a respeito da duração da pesquisa de campo, da importância do aprendizado da língua nativa, mas não os punha de fato em prática. Suas experiências de pesquisa de campo foram muito curtas - em geral, durante o verão, levando três meses - e envolviam a contratação de intérpretes e a recepção de informantes em sua casa, aos quais ele pagava por entrevistas e informações. O problema é que as informações prestadas por esses informantes-chaves se tornavam o grosso do material etnográfico. Melville e Frances participavam, claro, de cerimônias religiosas e outros tipos de eventos da vida das pessoas que eles estavam estudando. Há várias questões sobre a validade ou legitimidade do trabalho de campo deles que têm sido discutidas por pesquisadores como Richard e Sally Price (2003), Suzanne Blier (1989) e outros.

A viagem mais longa do casal Herskovits foi ao Brasil, entre 1941-42. Mas não podemos esquecer que ao menos metade do ano foi dedicada a conferências e encontros com outros pesquisadores, com rápidas viagens a diferentes locais, como Rio de Janeiro, Porto Alegre e Recife. Sua pesquisa de campo em Salvador 
durou cerca de seis meses. Por mais curtas que tenham sido tais pesquisas, elas foram, contudo, capazes de produzir um incrível montante de material etnográfico. Afinal, dessas breves incursões ele foi capaz de extrair um número de livros e artigos realmente surpreendente. E Frances contribuía imensamente. Ela era uma ótima pesquisadora de campo e tinha facilidade com o aprendizado de línguas estrangeiras, além de auxiliar com a redação. Inicialmente, ela tentou ser escritora, viajando para a França, para a Itália, mas não foi bem-sucedida. Ela escreveu uma novela e Herskovits tentou publicá-la, encaminhando os originais a vários editores de Nova York. O manuscrito nunca foi aceito e ela acabou queimando a única cópia. Segundo sua filha, Frances dizia que somente deveria ser incluída como coautora com Melville em obras antropológicas nas quais ela tivesse contribuído com mais de cinquenta por cento do texto. Tenho a impressão, porém, que ela fez muito e não foi creditada como coautora em algumas obras para possivelmente não ofuscar a carreira do marido. Ainda assim, a produção acadêmica de Herskovits foi inacreditável.

Essa é uma boa introdução para o nosso próximo tema. Nos anos de 1928 e 1929, Herskovits fez pesquisa de campo no Suriname; em 1934, no Haiti; em 1939, em Trinidad. Em quais aspectos a antropologia de Herskovits difere da antropologia do Caribe que veio antes?

KAY: Antes de Herskovits, as pesquisas de campo no Caribe eram conduzidas por etnólogos amadores ou folcloristas. Como mencionei, Elsie Parsons pesquisou na Jamaica, Haiti e Martinica. Outro exemplo é Fernando Ortiz, em Cuba. Inicialmente, ele se interessou pelas práticas religiosas afro-cubanas a partir de uma perspectiva da antropologia forense ou criminal. Apenas mais tarde foi cooptado pelo movimento Afro-Cubano, entre os anos de 1920 e 1930, tornando-se um defensor da religiosidade afro-cubana, encarada como uma parte integrante de sua cultura. Jean Price-Mars coletou material folclórico e, na condição de descendente de negros do norte do Haiti, queria encorajar todos os haitianos a abraçar seu passado africano em vez de continuar a olhar para os modelos culturais europeus. Lydia Cabrera, folclorista cubana, cunhada de Ortiz, pesquisou um pouco depois, entre os 1930 e 1950. Cito ainda Rómulo Lachatañaré, outro pesquisador cubano, que Ortiz considerava, não sem condescendência, como seu protegido. Ele morreu jovem num trágico acidente aéreo e deixou um volume importante sobre Santería.

No Suriname, havia o etnólogo holandês Jonkheer L. C. van Panhuys, que ajudou o casal Herskovits em sua pesquisa de campo. O médico nova-iorquino Morton C. Kahn escreveu um livro sobre os Saramaka do Suriname (1931). Foi Kahn quem guiou o casal Herskovits em sua primeira viagem à região, no ano de 1928. Andrew Carr, folclorista de Trinidad, e Andrew Pearse, sociólogo inglês trabalhando em Trinidad, conduziram pesquisas etnográficas, sobretudo 
nos anos de 1940 e 1950. O etnomusicólogo norte-americano Alan Lomax, o sociólogo norte-americano George Eaton Simpson e o folclorista norte-americano Harold Courlander foram ao Haiti nos anos 1930, aproximadamente no mesmo período em que Herskovits esteve lá. Katherine Dunham, dançarina, coreógrafa e antropóloga afro-americana, estudante de pós-graduação de Herskovits na Northwestern, pesquisou, inicialmente, no Haiti, na Jamaica e em outros lugares.

Além de Price-Mars, no Haiti os etnólogos eram os "três D" - François Duvalier, Lorimer Denis e Louis Diaquoi - que, subsidiados pela pesquisa etnológica, promoveram o "Noirisme", movimento que procurou evidenciar as raízes africanas do Haiti, e outras ideias nacionalistas. J. C. Dorsainvil enveredou para uma inclinação mais psicológica. Havia ainda etnólogos que justificavam a ocupação norte-americana no Haiti - que teve início em 1915 e terminou no verão de 1934, quando o casal Herskovits fazia seu trabalho de campo -, através de um racismo velado e descrições escabrosas do vodu. O livro de William Seabrook, The Magic Island, de 1929, poderia ser enquadrado nessa categoria.

No Caribe Britânico, havia a tradição dos relatórios etnográficos redigidos por administradores e governadores coloniais, especialmente interessados nos aspectos exóticos das manifestações religiosas afro-caribenhas. Penso, por exemplo, em Sir Henry Hesketh Bell e Sir Reginald St. Johnston. Há muito mais do que essa curta lista que eu lhe apresentei. Muitos deles são o que podemos chamar de etnólogos amadores - não para diminuir suas contribuições, mas eles não dispunham de treinamento profissional.

Nesse sentido, Herskovits foi um pioneiro quando fez pesquisa de campo em 1928 e 1929 no Suriname, em 1934 no Haiti e em 1939 em Trinidad. No Suriname, ele e Frances aportaram com conexões preestabelecidas. Herskovits começou a ler a obra de Ortiz e em seguida os escritos de Nina Rodrigues, o que não deixa de ser irônico, porque Ortiz e Nina Rodrigues se afinavam com certas formulações de Cesare Lombroso, o famoso criminologista italiano. Extraiu deles informações e evidências sobre as sobrevivências culturais africanas, deixando de lado toda a discussão sobre os efeitos deletérios da miscigenação racial para a modernização de seus respectivos países. Quando o casal chegou ao Suriname, a ideia era que Frances permanecesse na cidade, em Paramaribo, considerada mais segura, enquanto Melville iria para o interior, supostamente mais perigoso. Entretanto, ele adoeceu e Frances conduziu a pesquisa de campo antes de ele começar a sua própria pesquisa. Ela fez pesquisas principalmente com mulheres na cidade de Paramaribo, coletando materiais folclóricos e informações gerais sobre vida das mulheres. Ele, por sua vez, foi ao interior com guias e fez pesquisa como os Saramaka, interessado principalmente nas cerimônias e crenças religiosas, bem como, em menor grau, nas questões de parentesco.

Em 1931, eles foram para a África, para o Daomé, para a Nigéria e para a Costa do Ouro. O pressuposto era que a força cultural dominante de Saint-Do- 
mingue, a designação oficial do Haiti antes do sucesso da Revolução Haitiana, em 1804, provinha dos escravos trazidos do Daomé. Os Herskovits desembarcaram no Haiti com isso em mente e foram beneficiados pelo auxílio de Price-Mars, que os encontrou em sua chegada e viabilizou o local para a pesquisa de campo na comunidade dos Mirebalais. Já mencionei que a Marinha norte-americana ocupou o Haiti em 1915 e deixou-o no verão em que o casal Herskovits pesquisava, em 1934. Herskovits registrou a retirada das tropas, mas não creio que tenha levado tal fato em consideração, não se preocupando com as relações entre antropólogos norte-americanos e a população local. De fato, Mirebalais havia sido o palco de significativas lutas entre os rebeldes, os Cacos, e a Marinha norte-americana.

Enquanto faziam o trabalho de campo, eles levavam informantes para sua casa e assistiam a diferentes tipos de cerimônias públicas. Aos informantes faziam uma bateria de perguntas, que seguiam o seguinte padrão: "Se uma mulher tiver gêmeos, o que acontece?"; "Se o bebê nascer na sexta-feira, o que acontece?”. Perguntas desse tipo, a maior parte referida a situações hipotéticas (HERSKOVITS, 1966). Da pesquisa no Haiti surge o conceito de "socialized ambivalence" [ambivalência socializada]. Herskovits escreveu poucas páginas sobre o conceito em seu livro Life in a Haitian Valley (1937), e depois nunca mais voltou ao assunto. De acordo com ele, a "socialized ambivalence" seria a causa da instabilidade política do Haiti. Ele não atribuía essa suposta instabilidade à hostilidade sofrida pela primeira república negra no mundo de parte dos países circunvizinhos, mas à "socialized ambivalence". Segundo ele, teria havido uma aculturação incompleta: em vez de um amálgama harmonioso entre culturas distintas, uma disjunção que provocava nos haitianos distúrbios e instabilidade psíquica.

Ainda houve, no Haiti, a análise da possessão espiritual no vodu...

KAY: Herskovits contribuiu bastante para o entendimento da possessão espiritual no vodu como algo cultural e completamente admissível em um contexto particular. Ele contestava aqueles que, incluindo escritores haitianos, defendiam ser a possessão um fenômeno psicopatológico, resultado de processos psíquicos anormais em andamento. Dentro da perspectiva do relativismo cultural, Herskovits corretamente reivindicou que a possessão é um fenômeno ou um fato sociocultural. Ao mesmo tempo, ele não criticou a possessão nem tampouco as práticas e representações religiosas que impediam os haitianos de entender seu próprio contexto social, isto é, o contexto do subdesenvolvimento e da discriminação, a dificuldade de acesso a recursos e assim por diante. De modo algum Herskovits utilizava uma perspectiva materialista para os fenômenos que ele estudava...

É possível encontrar, tal como na pesquisa no Haiti, um conceito analítico importante formulado a partir da pesquisa em Trinidad? 
KAY: Em 1939, o casal Herskovits passou o verão em Trinidad, em uma vila remota na costa nordeste chamada Toco. A situação era diferente do Haiti porque eles estavam estudando tradições religiosas protestantes que haviam se combinado com formas culturais e ideologias religiosas afro-americanas. Situação diferente, portanto, das tradições católicas que ele estudou no Haiti e, depois, no Brasil. Nessa pesquisa, ele faz uso do termo "reinterpretação", central em seu arcabouço teórico-metodológico, e que se refere ao processo pelo qual "antigos significados se adscrevem a novos elementos ou através do qual valores novos mudam a significação cultural de velhas formas". Herskovits tentava descrever como africanos envolvidos em processos diaspóricos negociam sua experiência de vida em meio ao contexto colonial imposto pelas nações europeias.

No artigo "Melville J. Herskovits and Caribbean Studies: a Retrospective Tribute" (1964), Sidney Mintz declara: "Nenhum etnólogo do Caribe pode afirmar que não foi influenciado pelo trabalho de Melville Herskovits. Seu nome e suas obras - às vezes, sob teste ou ataque - são referidos em quase todos os artigos e livros antropológicos de relevo sobre a região publicados ao longo de três décadas. Pesquisadores estrangeiros, incluindo os principais nomes da etnologia em países do Caribe, repetidamente reconhecem seu débito. Por sua vez, seus alunos muito contribuíram para os estudos do Caribe"(MINTZ, 1964, p. 50). Como você discutiria essa influência em termos de uma agenda antropológica? Além disso, você poderia comentar sobre os alunos e discípulos de Herskovits que fizeram pesquisas de campo no Caribe?

KAY: Esse é um artigo que Sid [Sidney Mintz] escreveu em 1964, pouco após a morte de Herskovits. Eu acho que desde então a influência de Herskovits sofreu um movimento de idas e vindas, por assim dizer. É claro que ele foi um pioneiro na pesquisa no Caribe. Quer se concorde ou não com os resultados alcançados por Herskovits, os pesquisadores devem lê-lo, como eu mesmo o fiz nos anos 1980.

Herskovits treinou alguns de seus estudantes em pesquisa de campo no Caribe. Mencionei Katherine Dunham, dançarina e antropóloga que estudou na Universidade de Chicago e começou sua pesquisa de doutorado na Northwestern, sob a orientação de Herskovits. Ela não concluiu sua tese, pois estava mais interessada em dança e se iniciou na religião vodu no Haiti. Anos depois, fundou uma companhia de dança que se tornou mundialmente famosa. Em alguns casos, Herskovits sugeria aos estudantes que iriam fazer pesquisa de campo extensiva na África que, antes, realizassem incursões de verão em outro "lugar negro" [black place]. Assim, ele enviou William Bascom para a Carolina do Sul, com o objetivo de levantar informações entre os Gullah, antes de partir para a Nigéria. David M. Ames pesquisou em Cuba e somente depois viajou para o Senegal e a Nigéria. Bascom também fez pesquisa de campo em Cuba, retraçando as conexões entre Nigéria e a ilha caribenha. 
Alguns de seus alunos, porém, fizeram pesquisa de campo no Caribe. Daniel Crowley obteve seu doutorado com pesquisa no Caribe. Richard Waterman defendeu uma tese sobre música em Trinidad. No final dos anos 1950, Margaret Katzin pesquisou as "Higglers" na Jamaica. Ruy Coelho, que veio do Brasil e fez pesquisas de campo em Honduras, entre os Caraíbas Negros, agora chamados de Garífunas, descendentes de escravos que escaparam e se misturaram com nativos da Ilha de St. Vincent, após o que foram deportados pelos ingleses para a costa da América Central.

E há ainda um número de pesquisadores que não foram necessariamente seus alunos, mas que tomaram de empréstimo alguns temas de Herskovits em pesquisas no Caribe. É o caso, por exemplo, do sociólogo George Eaton Simpson - admirador de Herskovits, sobre quem escreveu uma pequena biografia -, que pesquisou no Haiti, Jamaica e Trinidad.

Creio que podemos avançar para a segunda parte desta entrevista. No periodo do pós-guerra, houve na região do Caribe duas frentes de investigação de grande impacto. De um lado, a realização do "People of Puerto Rico Project", que redefiniu a discussão sobre aculturação e sobre o contínuo folk-urbano ao enfatizar a adaptação de "subculturas" a fatores de ordem ecológica e à imbricação das dimensões locais e transnacionais a partir de uma pesquisa coordenada pelo antropólogo Julian Steward, em várias regiões de Porto Rico. De outro lado, houve um grande debate sobre a estrutura e a composição da família negra. Você poderia discorrer sobre a importância dessas duas frentes e sua ligação com as pesquisas antropológicas pioneiras no Caribe? Estou pensando na centralidade da discussão da família negra nas pesquisas de Herskovits.

KAY: Durante os anos 1940, um tema central de discussão na antropologia do Caribe foi a estrutura e a organização da família negra. Em certa medida, essa discussão envolve Herskovits e aquilo a que alguns se referem como o "debate" com o sociólogo afro-americano E. Franklin Frazier. Em linhas gerais, Frazier defendia que, por força das condições terríveis impostas pelo regime de trabalho escravista, a estrutura familiar africana não teria sobrevivido no Novo Mundo. Por conseguinte, a presença de núcleos familiares liderados por mulheres e supostamente desorganizados seria o resultado da escravidão e da situação em que os indivíduos, encarados como propriedades passíveis de serem negociadas, não conseguiam estabelecer uma estrutura familiar sólida. Em oposição, Herskovits e outros sustentavam que a presença de mulheres no comando das famílias e grupos domésticos e a poligamia masculina seriam sobrevivências de padrões de comportamento africanos. Herskovits e Frazier concordavam em muitas coisas e suas posições não eram tão antagônicas. Frazer admitia que sobrevivências africanas poderiam ter persistido nas esferas religiosa e cultural, apenas rejeitava-as no estudo da família afro-americana. Herskovits e Frazier brincavam entre si sobre o "debate". Eles eram amigos e colegas. 
O debate sobre a família negra começou com E. Franklin Frazier e seu livro The Negro Family in the United States (1939). A partir daí a questão se estendeu para o sul do Caribe quando, em 1940, a Grã-Bretanha aprovou o Colonial Development and Welfare Act. Nos anos 1930, houve um número significativo de revoltas e greves no Caribe Britânico, quando a população local protestou contra a continuidade da pobreza e a legislação que impedia o direito ao voto. Isso, claro, na esteira da Grande Depressão, quando os preços do açúcar, o principal produto de exportação da região, atingiram valores muito baixos. Havia um alto índice de desemprego, fome e crescente pobreza. Imediatamente antes do início da Segunda Guerra Mundial, os ingleses enviaram uma comissão de inquérito, a Moyne Commission, ${ }^{2}$ para apurar os fatos. Mas a situação averiguada e relatada pela comissão era muito prejudicial para a administração colonial. De fato, o relatório da Moyne Commission foi publicado apenas depois do final de guerra. De qualquer modo, o Parlamento Britânico aprovou o Colonial Development and Welfare Act em 1940, que forneceu recursos às colônias britânicas e também providenciou dinheiro para a pesquisa social, pesquisa na área de agricultura e questões afins. T. S. Simey, sociólogo britânico da Universidade de Liverpool, foi ao Caribe e escreveu um livro sobre a estrutura da família nas Índias Ocidentais, no qual ele argumentava que boa parte da pobreza no Caribe poderia ser imputada à chamada família desorganizada afro-caribenha. O livro, Welfare and Planning in the West Indies (1946), desencadeou muitas pesquisas sobre a família afro-caribenha nas quais os autores tentavam atribuir as razões para o predomínio da matrifocalidade e o alto índice de filhos ilegítimos, que chegava a mais de $70 \%$ dos nascimentos totais em algumas ilhas.

Assim, o debate entre Herskovits e Frazier, de certo modo, e na medida em que é um debate, tornou-se importante no Caribe para se responder a essas questões entre os anos 1940 até os 1980. Tornou-se uma preocupação para os antropólogos. M. G. Smith e R. T. Smith conduziram pesquisas sobre a família e um grande número de estudos explorou essas questões e tomaram partido. Não apenas na antropologia, mas também na sociologia. Ao mesmo tempo, havia o conceito de "cultura da pobreza" formulado por Oscar Lewis, com base em suas pesquisas em Porto Rico e México. Vários pesquisadores saíram a campo e tentaram encontrar e documentar a cultura da pobreza. Eu acho que Lewis, um marxista, foi utilizado erroneamente e, até certo ponto, continua mal compreendido - ainda que parte das críticas ao conceito esteja, a meu ver, correta.

Quanto ao "People of Puerto Rico Project", no final dos anos 1940, Julian Steward e um grupo de alunos da Universidade Columbia que se tornariam antropólogos muito famosos - Robert Manners, Sidney Mintz e Eric Wolf, para

\footnotetext{
${ }^{2}$ Também conhecido como Report of West India Royal Commission, o relatório expôs as péssimas condições de vida das colônias britânicas na região ao ser finalmente publicado na íntegra, em 1945.
} 
citar alguns - deu início ao projeto, cujos resultados foram publicados no livro The People of Puerto Rico: a Study in Social Anthropology (1956), organizado por Julian Steward e contendo artigos dos alunos. Houve, com o projeto, uma mudança efetiva de paradigma: os estudos do Caribe se deslocaram da perspectiva culturalista para questões de poder, o impacto do legado colonial e suas continuidades. A pesquisa enfocou a questão do desenvolvimento, olhando para o Estado e para a economia global - avaliando o impacto das forças da economia global sobre as populações locais, bem como suas respostas, também em nível local. Foi realmente inovador, mas, infelizmente, uma inovação que não inspirou um modelo a ser seguido, até ser retomado pelos estudos caribenhos nos anos 1970, quando se pode distinguir a influência de certa antropologia marxista nas pesquisas.

Apenas para encerrar esse raciocínio: você acha que a clivagem representada pelo Puerto Rico Project é uma espécie de ruptura radical ou podemos encontrar algumas continuidades com os estudos antropológicos anteriores sobre o Caribe?

KAY: Julian Steward assumiu uma abordagem neoevolucionista, quase materialista, que se opunha ao culturalismo boasiano. Herskovits, no começo dos anos 1950, escreveu o livro Franz Boas, the Science of Man in the Making (1953), que constituiu, no fundo, uma defesa da posição boasiana à luz das críticas lançadas por Steward, Leslie White e outros. Acho que Puerto Rico Project foi de fato uma ruptura, a partir de uma abordagem mais materialista, na antropologia em geral e na antropologia do Caribe em particular. Eu não consigo identificar algo parecido ocorrendo antes e mesmo anos depois, pois a pesquisa não se tornou um paradigma, seus insights não foram seguidos como modelos, pelo menos não imediatamente. Em minha opinião, tal fato mostra que a discussão antropológica nos Estados Unidos, ao longo da década de 1950, ainda girava em torno da agenda e da abordagem boasiana, pois parte da geração dos alunos de Boas, como, por exemplo, Herskovits e Alfred Kroeber, ainda estava em cena, atuando. E o impulso deste projeto foi uma espécie de oposição ao núcleo culturalista boasiano da disciplina.

No verbete "Caribbean", inserido na Encyclopedia of Social and Cultural Anthropology, você declarou: "Pode-se afirmar que a antropologia social e cultural do Caribe fez-se periférica para o núcleo da disciplina, por força da maneira como a antropologia se profissionalizou e pelos seus requisitos epistemológicos concomitantes para observar, e criar, quando necessário, culturas primitivas e estruturas sociais. Séculos de colonialismo hegemônico, migração, escravidão e trabalho forçado, miscigenação, e culturas 'derivativas', arrancadas de seus lugares de origem, tudo convergiu para que a antropologia definisse o Caribe como 'híbrido'e 'crioulo"' (Yelvington, 1996, p. 89). O que a antropologia do Caribe nos legou? Sincretismo? Diáspora? Crioulização? 
KAY: Alguns pesquisadores afirmaram que certos tropos e metáforas tornaram-se paradigmáticos para certas regiões etnográficas. Assim, os antropólogos não podem ir à Índia sem olhar para as castas. Elas se tornaram uma unidade central de investigação, excluindo muitas outras questões sobre gênero, classe, poder etc. No Caribe, temas como família, religião e performance tornaram-se centrais, atraindo estudantes interessados em pesquisar, por exemplo, a Santería Cubana, ou, na Jamaica, a religião Rastafari, ou questões relacionadas à família e identidade. Entre as décadas de 1930 e 1960, o Caribe foi uma região etnográfica de menor importância para a discussão antropológica. Mesmo para os alunos de Herskovits, o Caribe era, como mencionei, um lugar de passagem, para se ir antes da pesquisa de campo "para valer" na África, Ásia ou no Pacífico. O Caribe era considerado uma área geográfica e culturalmente muito próxima aos Estados Unidos. Era muito familiar. As pessoas falavam línguas europeias, ao menos oficialmente, e a região não era exótica o suficiente para os padrões da pesquisa antropológica norte-americana. Mas tal situação mudou muito nos últimos anos.

De fato, no mesmo verbete você ainda diz: "A antropologia do Caribe sempre esteve envolvida com questões que se tornaram populares na disciplina como um todo nos anos 1980 e 1990, incluindo colonialismo, história e antropologia, processos diaspóricos, o sistema de plantation, gênero, etnicidade" (Yelvington, 1996, p. 89). Quais foram as mudanças, de um lado, na realidade social, econômica e politica do mundo e, de outro, no interior das discussões antropológicas que explicam esse recente interesse?

KAY: Creio que você está certo em sugerir que parte da resposta para a progressiva centralidade adquirida pela região caribenha na disciplina antropológica deve ser buscada em mudanças econômicas e políticas em escala mundial. No caso dos Estados Unidos, a aprovação de novas leis de imigração, a partir de 1965 , e o aumento da taxa de migrantes caribenhos desde então realmente suscitaram maior interesse pelo - e conscientização a respeito do - Caribe. Também acho que o advento da "condição pós-moderna", conforme designação de David Harvey, na qual a nova face do capitalismo significa mais migração, acelerou o interesse pela região, que cada vez mais se torna um destino de turismo de massa e chama a atenção por conta da riqueza de sua cultura popular, como seus ícones da música, Bob Marley e Celia Cruz, e escritores como Derek Walcott ou Jamaica Kincaid. Portanto, há uma série de fatores sociais e econômicos que explicam tal atração.

Não me interprete mal, mas talvez a ideia de "hibridismo" e "crioulização" e seus tropos e metáforas correspondentes possam ser usados apenas como uma forma diferente de exotizar e erotizar o Caribe. Por outro lado, o caso do Caribe ajudou, de maneira legítima, a trazer questões sobre hibridismo e crioulização 
para o centro da discussão antropológica. Para tanto, acho que sim: você tem que localizar as mudanças socioeconômicas e políticas mais amplas.

Como a antropologia do Caribe se vê envolvida com as estratégias pós-coloniais de representação?

KAY: Os antropólogos são sensíveis às críticas feitas por integrantes das sociedades que eles estudam. Bronislaw Malinowski escreveu cinco livros sobre os ilhéus de Trobriand, mas algum trobriandês leu esses livros quando foram publicados? No Caribe, atualmente, há escritores e intelectuais que compartilham o mesmo espaço e circuito intelectual no qual se encontram antropólogos e cientistas sociais. Não podemos esquecer que, em 1992, três escritores caribenhos ganharam os três principais prêmios literários do mundo: Derek Walcott, que é de Santa Lucia, conquistou o Prêmio Nobel; Dulce María Loynaz, de Cuba, venceu o Prêmio Cervantes na Espanha; e Patrick Chamoiseau, da Martinica, arrebatou o Prix Goncourt na França. Creio que os debates pós-coloniais e críticas, muitas vezes liderados por intelectuais pós-coloniais, são levados em conta por antropólogos e eles também tentam incorporá-los em suas teorizações sobre o Caribe.

Quais são os principais temas antropológicos e principais pesquisadores do Caribe que surgem a partir dos anos de 1980 e 1990?

KAY: Alguns dos temas que emergiram nos anos 1980 e 1990 e que continuam até o presente se referem a amplos processos globais. Há, assim, uma ênfase nas mudanças econômicas provocadas pela política neoliberal nas economias locais do Caribe. Karla Slocum (2006) fez pesquisa sobre a indústria da banana em Santa Lucia, documentando as respostas locais às mudanças que vêm ocorrendo nas políticas e taxas de importação da União Europeia e dos Estados Unidos. No contexto pós-colonial, antropólogos estão investigando questões que se ligam aos efeitos do encerramento do colonialismo. Há alguns pesquisadores interessados em nacionalismo, raça e etnicidade para entender o que o legado colonial deixou para o Caribe. Penso em Deborah Thomas (2004) e sua pesquisa na Jamaica como um momento-chave. Questões que retornam às perguntas de Herskovits ressurgem no enquadramento da diáspora e da migração. É o caso, por exemplo, do trabalho organizado por Nancy Foner (2001) sobre imigrantes caribenhos em Nova York. Ao mesmo tempo, questões colocadas pela antropologia histórica continuam a ser pertinentes. Sidney Mintz continuou a fazer a pesquisa sobre o Caribe, e seu livro Sweetness and Power: the Place of Sugar in Modern History (1985) investigou o papel da indústria de açúcar do Caribe na produção da revolução industrial e da modernidade. 
Na nova ordem econômica, temos discussões sobre gênero e trabalho, como a pesquisa de Carla Freeman (2000) sobre o papel das mulheres e das questões de gênero na indústria de processamento de informações offshore em Barbados, algo realmente importante. O compromisso com a história implica também no avanço da pesquisa em história oral e a história que não se encontra necessariamente nos arquivos, como as obras de Richard Price (2008) entre os Saramaka. Stephan Palmié (2008), a partir do caso da Santería em Cuba, discute como a "África" é produzida no Caribe para, em seguida, vincular esse movimento a processos mais amplos de representação.

Uma vez que a produção artística do Caribe também se tornou muito mais visível e disponível, tradições artísticas e celebrações coletivas tornaram-se objeto de estudo. Pesquisadores como Kenneth Bilby (1995), Philip Scher e Garth Green (2007), entre outros, estão olhando para as tradições carnavalescas e refletindo como hoje em dia o carnaval é parte de processos transnacionais. A política da identidade permanece um tema importante de investigação, especialmente porque muitos estudos interessantes interrogaram-se sobre questões de minorias e maiorias nas sociedades pós-coloniais. Penso no trabalho de Aisha Khan (2015) entre os hindus e os muçulmanos indianos em Trinidad, por exemplo.

Há ainda os temas relacionados com a modernidade, com a produção de mercadorias para mercados nacionais e internacionais, consumo de massa, uso de tecnologia e comunicações, como nos livros Modernity, an Ethnographic Approach: Dualism and Mass Consumption in Trinidad (1994) e Capitalism: an Ethnographic Approach (1997), ambos organizados por Daniel Miller. E também The Cell Phone: an Anthropology of Communication (2006), de Daniel Miller e Heather A. Horst, que discute como o telefone celular na Jamaica facilita certos tipos de formas familiares de comunicação. De Daniel Miller e Don Slater, temos Internet: an Ethnographic Approach (2000). Há ainda estudos sobre turismo, incluindo turismo sexual, e até mesmo sobre a operação bancária em paraísos fiscais, como o trabalho de Bill Maurer (1997). Como você pode imaginar, pesquisas antropológicas sobre os impactos locais das mudanças climáticas estão emergindo, em compasso com um enfoque cada vez mais técnico sobre a pesca e conservação ambiental. Creio que tais temas, que mencionei de forma um tanto aleatória, estão bem estabelecidos e serão desenvolvidos pelos antropólogos ao longo das próximas décadas. 
Muito obrigado pela entrevista.

KAY: Disponha, o prazer foi meu.

\section{Referências bibliográficas}

BLIER, Suzane Preston. Field Days: Melville J. Herskovits in Dahomey. In: History in Africa 16, 1989. p. 1-22.

CORREAA, Mariza. História da antropologia no Brasil: 1930-1960 - testemunhos. São Paulo: Vértice/Editora Revista dos Tribunais; Campinas: Editora da Universidade Estadual de Campinas, 1987.

DARNELL, Regna. And along Came Boas: continuity and Revolution in americanist anthropology. Amsterdã/Filadélfia/Penn: John Benjamins, 1998.

FONER, Nancy (Ed.). Islands in the City: West indian migration to New York. Berkeley: University of California Press, 2001.

FRAZER, E., Franklin. The Negro Family in the United States. Illinois: The University of Chicago Press, 1939.

FREEMAN, Carla. High Tech and High Heels in Global Economy: women, work and pink-color identities in the Caribbean. Durham/Nova York/Londres: Duke University Press, 2000.

GREEN, Garth; SCHER, Philip. Trinidad Carnival: the cultural politics of transnational festival. Bloomington: Indiana University Press, 2007.

HESKOVITS, Melville. Rebel Destiny: among the Bush Negroes of Dutch Guiana (with Frances Herskovits). Nova York: Whittlesey House, 1934.

Dahomey: an ancient West African kingdom. Nova York: J. J. Augustin, 1937.

Life in a Haitian Valley. Nova York: Knopf. 1937.

Trinidad Village (with Frances Herskovits). Nova York: Knopf, 1946.

Franz Boas, the Science of Man in the Making. Nova York: Scribners, 1953.

The Hypothetical Situation: a technique of field research. In: The New World Negro: selected papers in Afroamerican studies. Indiana: Indiana University Press, Minerva Press, 1966. p. 62-71.

JACKSON, Walter. Melville Herkovits and the Search for Afro-American Culture. In: STOCKING JR., G. Malinowski, Rivers, Benedict and others. Essays on culture and personality. "History of Anthropology", v. 4. Madison: The University of Wisconsin Press, 1986.

KHAN, Aisha. Islam and the Americas. Gainsville: University Press of Florida, 2015.

KHAN, Morton C. Djuka: the Bush Negroes of Dutch Guiana. Nova York: Viking, 1931. 
KUKLICK, Henrika. The Savage within: the social history of British anthropology, 1885-1945. Cambridge: Cambridge University Press, 1991.

LANGHAN, Ian. The Building of British Anthropology: W. H. Rivers and his Cambridge disciples in the development of kingship studies, 1898-1931. Dordrecht, Boston and London: D. Reidel, 1981.

MAGLOIRE, Gérard; YELVINGTON, Kevin A. "Haiti and the Anthropological Imagination". Gradhiva (N.S.) 1, 2005. p. 127-52.

MANUEL, Peter; BILBY, Kenneth; LARGEY, Michael (Eds). Caribbean Currents: Caribbean music from rumba to reggae. Filadélfia: Temple University Press, 1995.

MICELI, Sergio (Org.). História das ciências sociais no Brasil. v.1. São Paulo: Editora Sumaré, 1989.

MILLER, Daniel. Modernity, an Ethnographic Approach: dualism and mass consumption in Trinidad. Oxford: Berg Publishers, 1994.

Capitalism: an ethnographic approach. Oxford, UK; Washington, D.

C.: Berg, 1997.

MILLER, Daniel; SLATER, Don. Internet: an ethnographic approach. Oxford: Berg, 2000.

MILLER, Daniel; HORST, Heather. Cell Phone: an anthropology of communication. Oxford; Nova York: Berg, 2006.

MINTZ, Sidney. Melville J. Herskovits and Caribbean Studies: a retrospective tribute. Caribbean Studies, 4(2), 1964. p. 42-51.

Sweetness and Power. the place of sugar in modern history. Nova York: Viking, 1985.

PALMIÉ, Stephan. Africas of the Americas: beyond the search for origins in the study of Afro-Atlantic religions. Leiden/Boston: Brill, 2008.

PRICE, Richard; PRICE, Sally. The Roots of the Roots or How Afro-American Anthropology Got Its Start. Chicago: Prickly Paradigm Press, 2003.

PRICE, Richard. Travels with Tooy: history, memory and the African American imagination. Chicago: University of Chicago Press. 2008

STEWARD, Julian H. (Ed.) The People of Puerto Rico: a study in social anthropology. Illinois: University of Illinois Press, 1956.

SLOCUM, Carla. Free Trade \& Freedom: neoliberalism, place, and nation in the Caribbean. Ann Arbor: University of Michigan Press, 2006.

SIMEY, T. S. Welfare and Planning in the West Indies. Oxford: Claredon Press, 1946.

THOMAS, Deborah A. Modern Blackness: nationalism, globalization, and the politics of culture in Jamaica. Durham: Duke University Press, 2004.

VANDERCOOK, John W. "Tom-Tom”. Nova York/Londres: Harper \& Brothers, 1926.

YELVINGTON, Kevin. The Context of Acculturation: the modernization 
process and occupational diversification in Trinidad and Tobago. M. A. degree in International Studies. Florida International University, Miami, 1985. Ethnicity, class, and gender at work in a Trinidadian factory. D.Phil. in Social Anthropology. Brighton, University of Sussex, 1990.

(Ed.). Trinidad Ethnicity. Knoxville: University of Tennessee Press/ Londres: Macmillan, Warwick University Caribbean Studies Series, 1993.

Producing Power. ethnicity, gender, and class in a Caribbean workplace. Filadélfia: Temple University Press, 1995.

Caribbean. In: BARNARD, A.; SPENCER, J. (Eds.) Encyclopedia of Social and Cultural Anthropology. Londres/Nova York: Routledge, 1996. p. 86-90. Herskovits' Jewishness. History of Anthropology Newsletter, v. 27, n. 2, 2000. p. 3-9.

"The Anthropology of Afro-Latin America and the Caribbean: Diasporic Dimensions". Annual Review of Anthropology 30, 2001. p. 227-60.

; MAGLOIRE, Gérard. Haiti and the Anthropological Imagination. Gradhiva (N.S.), n. 1, 2005. p. 127-52.

The Invention of Africa in Latin America and the Caribbean: political discourse and anthropological praxis, 1920-1940. In: YELVINGTON, K. A. (Ed.). Afro-Atlantic Dialogues: anthropology in the diaspora. Santa Fe, N.M.: School of American Research Press, 2006. p. 35-82.

. Melville J. Herskovits e a institucionalização dos estudos afro-americanos. In: PEREIRA, C. L.; SANSONE, L. (Eds.). Projeto Unesco no Brasil: textos críticos. Salvador (BA): Editora da Universidade Federal da Bahia, 2007. p. 149172 .

Melville J. Herskovits. In: DARITY JR., W. A. (Ed.). International Encyclopedia of the Social Sciences. Nova York: Macmillan Reference, v. 3, 2008. p. 466-7.

YOUNG, Michael W. The Ethnography of Malinowski: the Trobriand Islands 1915-18. Londres/Boston: Routledge \& Kegan Paul, 1979.

\section{autor Rodrigo Martins Ramassote}

Bacharel em Ciências Sociais pela Ufscar (2003). Mestre (2006) e doutor (2013) em Antropologia Social pela Unicamp. Atualmente, realiza Pós-doutorado no Departamento de Antropologia Social da Universidade de São Paulo (USP), com o auxílio de bolsa de pesquisa da Fapesp. Desde 2006, é técnico em Ciências Sociais pelo Iphan. 